\title{
The European Union's Politics of Identity and the Legacy of 1989
}

\author{
STEFAN AUER
}

The European Union loves anniversaries. To the extent that the European Union seeks to foster European identity, it is not surprising that it is increasingly deploying tools and methods that states use to create nations: commemoration of key moments in the nation's history serve as rallying points for national attachments, creating, or strengthening, a sense of national identity.

Europe is different to nations. The European Union is not a state and Europe struggles to turn its history, or, to be more precise, its many histories, into one unifying narrative. From the outset, the European project was based on a somewhat paradoxical relationship with the past. Europeans were initially united more by that which they rejected than that to which they aspired. In 1945, the great French poet Paul Valéry described the European predicament: 'We hope vaguely, we dread precisely.' ${ }^{1}$ What people vaguely hoped for was peace; what they dreaded was the devastation of past wars. To find more positive sources of identification in their past, Europeans had to reach back further, to the Enlightenment period and its cosmopolitan ideals, ${ }^{2}$ which found expression in Beethoven's Ninth Symphony with Schiller's Ode to Joy. It is thus fitting that the European Union adopted the tune of the symphony's finale as its anthem in $1986 .^{3}$

As successful as the project of Europe's unity has been in securing peace and prosperity underpinned by a strong commitment to liberal democracy, the European project was initially limited to Western Europe. The collapse of communism enabled Europe to reach beyond these limitations. For the first time in their turbulent histories, the nations of Europe in the West and in the East could pursue unity together. The peaceful revolutions in Central and Eastern Europe gave the European Union a new set of images and a date to remember: 9 November 1989 - the day on which the Berlin Wall lost its purpose.

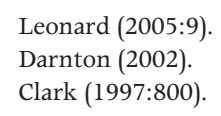


One of the first public celebrations of this event was the performance in the Schauspielhaus Berlin (East Germany) of Beethoven's Ninth Symphony by a multinational orchestra with musicians from Germany, Russia, the United Kingdom, the United States and France, and conducted by Leonard Bernstein. Responding to the spirit of the time - the concert took place only a few weeks after the demise of the wall-Bernstein felt justified in making a small but significant change to Schiller's lyric, substituting the word 'Freiheit' (freedom) for 'Freude' (joy). Ever since, the liberation of 1989 and Beethoven's famous finale seem to have gone hand in hand as two positive symbols of European unity. The same music accompanied celebrations of the 'big-bang' enlargement in May 2004, which brought eight countries from the former Eastern Bloc into the European Union, followed by the admission of Bulgaria and Romania in January $2007 .{ }^{4}$

Twenty years after the demise of communism, the European Union has succeeded in revamping its institutional architecture through the adoption of the Lisbon Treaty. The new Europe of 27 member states needs more, however, than new institutions; it requires a new self-understanding. Judging from a number of recent attempts by key EU actors, achieving a basic agreement about the 'meaning' of decisive events in Europe's recent past, including 9 November 1989, might prove at least as troublesome as the protracted process of institutional reform.

The main aim of this chapter is to show the limits of EU identity politics, with a particular focus on the legacy of 1989 in Poland, Germany and Europe at large. The first section of the chapter presents the traditional Western narrative of European unification from the Schuman declaration of 9 May 1950, which is celebrated officially as Europe's birthday, to the Treaty of Maastricht of 1993, which strengthened Europe's unity practically and symbolically through the creation of the European Union. The second section focuses on one recent EU attempt to assimilate 1989 into this preconceived narrative. The third section analyses the pitfalls of this attempt from a Polish perspective, contrasting official EU accounts with the nuances and historical sensitivities surrounding the demise of communism. The fourth, and last, section will show that even a more sensitive commemoration of the fall of the wall in Berlin on 9 November 2009 was not free of dissonance. This leads to the concluding remarks, which bring together the various strands of the key argument of the article, highlighting that the instrumentalisation of the legacy of 1989 could damage the European Union's credibility rather than enhance its legitimacy.

4 One of the best videos about EU enlargement is devoted to Bulgaria's accession: 'Bulgaria in EU: Ode to Joy' (<http://www.youtube.com/watch?v=5YRATI_jKU>, viewed 28 December 2009). Not surprisingly, the video produced by the EC audiovisual services to celebrate the 2004 enlargement is also underlined by Beethoven's Ode to Joy. 


\section{From Schuman to Maastricht: Europe Day and the European anthem}

The Schuman Declaration harks back to the legacy of World War II. The French Foreign Minister, Robert Schuman, was fully aware of the significance of its timing, 'almost five years to the day since Germany's unconditional surrender', 5 even though the actual release date of his plan was contingent on a series of negotiations between French, American and British partners. The declaration was aimed at the preservation of peace in Europe by elevating West Germany into an equal partner in pursuit of a European federation, which was to be accomplished by means of piecemeal economic cooperation. As Jean Monnet, the architect of the Schuman Plan, later recalled, in order to overcome traditional enmities between France and Germany, 'the Franco-German problem' had to be turned into 'a European problem' ${ }^{6}$ From the very beginning, the project was open to other European nations, with the notable exception of the countries under the Soviet sphere of influence. France and Germany were soon joined by Italy and the Benelux countries (Belgium, the Netherlands and Luxembourg).

According to Fabrice Larat, one of the key aims of Europe Day was to reaffirm ${ }^{7}$

the continuity between the objectives introduced at that time in the Schuman Declaration (Franco-German reconciliation, peace, stability, economical growth) and the basic principles of the European Union (willingness of the participating countries to restrict their own power, the abandoning of sovereign rights, and the rejection of nationalism).

It is worthwhile remembering that many contemporaries did not perceive the Schuman Declaration as a major event with far-reaching consequences. The fact that it is considered a milestone in Europe's integration nowadays is largely a testimony to the success of the European Commission and other EU institutions in making it so. Europe Day has been officially celebrated since 1985.

Yet, there are limitations to Europe Day as a symbol that unites all the peoples of Europe. Unwittingly, it is also a reminder of the elitist and secretive nature of the project, at least originally. It remains one of the paradoxes of postwar European history that the western part of Europe gained an institutional dimension through the European Coal and Steel Community in 1952 and the European Economic Community (EEC) in 1958 at precisely the time when a popular European feeling of community was at a low ebb'. ${ }^{8}$ To protect peace

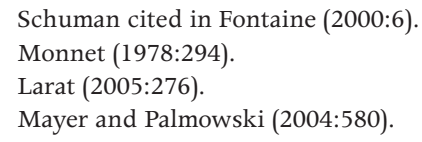


in Europe, the peoples of Europe had to be protected from themselves - from their fear and distrust of their neighbours, and their desire for revenge. Owing to such sentiments, a people's Europe had to be built largely without the people's involvement. Indeed, in the early stages of European integration, the project was shaped by 'Monnet's vision of the EEC as a technocratic creation that would bring about a thoroughly "modernized" Europe created by an enlightened bureaucracy'. ${ }^{9}$ This did not pose any significant problems as long as the European project did not have much effect on the daily lives of citizens.

The postwar transformation of Western Europe amounted to a 'quiet revolution' of a peculiar kind. ${ }^{10}$ This top-down revolution radically changed the relationship between nation-states by subordinating them to a supranational legal order, which was, however, created by distinctly moderate means. The key instrument in this transformation from the 1960s through to the 1980s was the European Court of Justice. ${ }^{11}$ It was only in the 1980s and the 1990s that European elites recognised and consolidated these revolutionary changes by undertaking ambitious institutional reforms that culminated in the creation of the European Union. With the increased push towards closer integration through the Single European Act in 1986 and the Treaty of Maastricht in 1993, questions of legitimacy and popular consent gained importance, leading to a concerted effort to foster European identity.

Radical institutional changes in the 1980s and 1990s were thus accompanied by an increased focus on the politics of identity, with the introduction of a number of official symbols of European unification. As noted above, these included Europe Day, the European anthem and European citizenship. If the Schuman Declaration, celebrated on Europe Day, can be seen as a practical answer to the prevalent negative sentiment in Europe immediately after World War II ('never again war'), ${ }^{12}$ the European anthem is the expression of the positive eighteenthcentury ideal of the universal brotherhood of man. While the former seeks to foster European unity on the shared sense of revulsion at Europe's history marred by excessive violence, the latter seeks to achieve this by reminding Europeans of their Enlightenment heritage, embodied in the ideals of the

\footnotetext{
9 Ibid., p. 580.

10 Weiler (1994).

11 As Eric Stein observed in a classic study (1981:1), 'tucked away in the fairyland Duchy of Luxembourg and blessed, until recently, with benign neglect by the powers that be and the mass media, the Court of Justice of the European Communities has fashioned a constitutional framework for a federal-type structure in Europe'.

12 This slogan usually entails, particularly in Germany, the rejection of the ultimate crime of World War II: 'never again Auschwitz.' In line with this, Helmut Dubiel (2003:68) described 'the Holocaust as a foundational myth for the European Union'. The nations in Central and Eastern Europe have sought to expand on this myth by including the rejection of Stalinism alongside Nazism in the European self-understanding. This cause has been advanced particularly in the European Parliament, which in September 2008 designated 23 August, the anniversary of the Nazi-Soviet non-aggression pact of 1939, as the 'European Day of Remembrance for Victims of Stalinism and Nazism'.
} 
French Revolution of 1789 (if not in its practice, which was also not free of violence). European citizenship combines the pragmatic spirit of the Schuman Declaration with the cosmopolitan ideal expressed in the European anthem. ${ }^{13}$ It is pragmatic in that it merely supplements, rather than substitutes, the existing national citizenship. Yet, by reminding Europe's citizens of rights they have as Europeans - particularly freedom of movement - European citizenship arguably enhances a sense of European identity. ${ }^{14}$

Almost at the same time as Western Europe accelerated its 'quiet revolution' from above, a bottom-up revolution was taking place in Central and Eastern Europe. This took political elites in the West by surprise. The European Economic Community and the European Union took a long time to develop an adequate response to a dramatically changed geopolitical situation. Twenty years later, however, insofar as the European Union wants to be seen as a 'people's Europe', it seems to make sense for it to claim ownership of the 'people's revolutions' of 1989. ${ }^{15}$

\section{November 1989 from an EU Perspective (Commemorated in May-June 2009)}

What better symbol could be found for a new Europe- one without borders and past enmities - than 9 November 1989, when the demise of the Berlin Wall marked the end of the postwar division of Europe? It appears that the European Union, having established an anthem and a Europe Day, seeks to appropriate a new symbol capable of eliciting true affection: the fall of the wall, with emotional images of people suddenly experiencing freedom. It was not just freedom of movement between one part of the city and another, but freedom from communist dictatorship that people celebrated on the streets of a reunited city, which was to lead to the reunification of Germany, and, eventually, the unification of the whole continent.

\footnotetext{
13 It is worthwhile noting that the anthem does this implicitly, for it has no lyrics. According to Caryl Clark (1997:801), the anthem is 'truly a bastard child of the Enlightenment: a song without words; hope without a text'. Yet, Clark's detailed study also shows why this was politically necessary: 'to sanction a German-language text would risk disturbing the ghost that still haunts the European Union - the ghost of Germany ascendant' (p. 803). Moreover, the ratification of the Lisbon Treaty in November 2009 further reduced the official status of the anthem, as there is no explicit reference to it in the way envisaged by the failed Constitutional Treaty. The European Union has thus an anthem without words that dares not speak its name.

14 Bruter (2005:156-8).

15 Very few serious commentators could be as blinded by their enthusiasm for the European Union as to consider it the main reason for the demise of communism. William Pfaff (2007), for one, celebrated the fiftieth anniversary of the Treaty of Rome by proclaiming: 'Fundamentally, the EU did it... The European Union, more than any other single factor, was responsible for the defeat of the Soviet Union in the cold war.'
} 
In May 2009, the audiovisual services of the European Commission released a three-minute-long video to mark the '20th Anniversary of democratic change in Central and Eastern Europe' (its official title). Its story is as simple as it is captivating. Against the background of an extremely brief recapitulation of key moments in the struggle against communism (Hungary 1956; Czechoslovakia 1968; Poland 1981; Lithuania, Latvia, Estonia 1989; Romania 1989), the short movie depicts a Europe without borders through the personal experience of someone born on that memorable day: 9 November 1989.

Here is the storyline in more detail. A baby boy was born at the very time when liberty was born in Berlin - liberty for Germany and the whole of Europe. Uplifting music underlines the young parents' joy over the newborn, reinforced through public joy over the fall of the wall (as can be seen on a television screen in the maternity ward). As the boy learns to walk, the countries of the former Eastern Bloc take their first steps towards national independence and freedom (Soviet troop withdrawal from Hungary in June 1991; independence of Lithuania in November 1991). When the boy turns six, the small German family drives for a holiday to France, experiencing the newly established Europe without borders ('Open borders', 1995). A fifteen-year-old boy celebrates the enlargement of the European Union ('Europe reunited', 2004). Finally, the twenty-year-old young man, taking a photograph of the Brandenburg Gate, is ambushed by his friends, who join him to celebrate his twentieth birthday.

Although this sanitised, politically correct depiction of birthday celebrations aimed to please everyone (somewhat implausibly, twenty-year-olds chose to celebrate with a strawberry cake and soft drinks!), it triggered a minor upheaval in the Polish media and on the pages of YouTube. From an EU perspective, the storyline made perfect sense. A lively and visually engaging production effectively assimilated the revolutions of 1989 into the established narrative of Western European integration. It is surely not accidental, for example, that the German family chose France as its holiday destination. The choice reinforced the common understanding that at the centre of the European project was the process of Franco-German reconciliation, which turned both countries into reliable partners for each other and Europe at large. For a long time, France and Germany have indeed been seen as the engine of European integration. After the demise of communism in Central and Eastern Europe, it was expected that this model of reconciliation could be extended to the whole continent.

Yet, even as the movie celebrated a Europe without borders - which became a reality through the Schengen Treaty in 1995-citizens from Poland and other countries of Central and Eastern Europe had to accept limitations on their freedom of movement. They could not work in Germany before 2011, for example, owing to a transitional measure that the old member states were allowed to apply to people from the new members states. France lifted its 
restrictions in July 2008, four years after the enlargement, having recovered from the somewhat paranoid fear of the 'Polish plumber', which contributed to the defeat of the Constitutional Treaty in the 2005 referendum in France. ${ }^{16}$

\section{Polish Responses: 'Nie ma wolności bez Solidarności' ${ }^{17}$}

From the Polish perspective, the timing of the video release could not have been worse. While the audiovisual services of the European Commission might have conceived it as a timely reminder of the fifth anniversary of enlargement (1 May 2004), Poles were about to celebrate the twenty-year anniversary of the first semi-free elections on 4 June 1989. Just as that key Polish event was at the time largely overshadowed by more tragic and dramatic developments in Chinathe violent suppression of the pro-democracy movement in Tiananmen Square provided far more exciting media images - the EU video prefigured that in 2009 Poland's peaceful revolution was going to be overshadowed by the celebrations of the fall of the Berlin Wall. As a number of Polish commentators and politicians observed, Poland's contribution was reduced, in the EU video, to a few seconds of footage of General Jaruzelski reading the martial law proclamation on 14 December 1981. There was no mention of Solidarność, or key personalities in the Polish struggle for liberty, such as John Paul II and Lech Wałęsa, and no reference to the round table discussions. ${ }^{18}$

Not surprisingly, then, Polish political elites across ideological divides, journalists and the people were united in their rejection of the EU video. Roza Thun, the then head of the EC Representation in Poland, denounced it as an 'idiotic error' (idiotyczny blad); ${ }^{19}$ Bogdan Zdrojewski, Minister of Culture, called it a 'serious error' (poważny bład); ${ }^{20}$ and Donald Tusk, the Prime Minister, called it a 'stupid blunder' (glupia wpadka). ${ }^{21}$ Poland's Ambassador to the European Union, Jan Tombiński, wrote a letter of complaint to Margot Wallström, the commissioner in charge of communication strategy, demanding alteration of the

\footnotetext{
16 Hainsworth (2006:108-9).

17 'There is no freedom without Solidarity' was a popular slogan in Poland in the 1980s. In allusion to this, Gazeta Wyborcza published a critical article about the EU video entitled 'Bruksela o wolności bez "Solidarności"' ('Brussels on freedom without "Solidarity"') (Uhlig 2009).

18 Jan Tombiński, Poland's Ambassador to the European Union, was right to point out that the Polish round table resonated with 'the archetype of the EU ideal' (Guzik 2009). Just as political negotiations were at the heart of the 'quiet revolution' (Weiler 1994) that radically transformed postwar Europe, the Polish round table discussions pioneered a model for the negotiated revolutions in Central and Eastern Europe.

19 TVN24.pl, 17 May 2009 (<http://www.tvn24.pl/-1,1600629,0,1,idiotyczny-blad-komisjieuropejskiej,wiadomosc.html>, viewed 5 January 2010).

20 Ibid.

21 Uhlig and Pszczółkowska (2009).
} 
video. ${ }^{22}$ In a similar vein, Bogusław Sonik, member of the European Parliament for Civic Platform (Platforma Europejska), wrote to the EC President, José Manuel Barroso, that 'artistic licence cannot be more important than historical facts' $^{23}$

Confronted with such a hostile reaction, the European Commission felt the need to respond, and released an amended version, which expanded on the footage of the Polish contribution, though it failed to satisfy most Polish commentators. In addition, the EC Representation in Poland in collaboration with the Office of the Committee for European Integration (UKIE) created a new video modelled on the original production but with a distinctly different focus. It was centred on a real person, Marta Włóka, a Polish student of Lódz University who was born on 4 June 1989. It presented a day in the life of Włóka alongside key moments in Polish post-communist history, including the country's entry into the European Union. The final scene shows Włóka saying a simple 'Dziękuję' ('thank you') directed presumably to all those who brought about a free Poland in a free Europe. $^{24}$

The controversy about the EU representation of 1989 is not a trivial matter; from a Polish perspective, the depiction of freedom without Solidarity is not just incomplete; it is offensive. Unwittingly, it also revives old traumas. It reminds Poles that when it mattered, the rise and fall of the Solidarity movement was not met with sufficient solidarity by leading politicians in Western Europe, particularly in Germany. Helmut Schmidt, the then West German Chancellor, was visiting East Germany on 13 December 1981, the day on which General Jaruzelski proclaimed martial law. Schmidt was unwilling to jeopardise the progress made in the German-German relationship under the social democratic strategy of Ostpolitik, even if this required a more muted response to events in Poland. Queried by West German journalists about the martial law declaration, Schmidt ended up agreeing with his host, the leader of the East German state, Erich Honecker, that Jaruzelski's radical step was necessary to preserve peace and political stability in Europe. Schmidt continued praising the visit as a sign of a 'good neighbourly relationship', which attracted fierce criticisms from the right-of-centre media. ${ }^{25}$ The editorials in the major left-wing weekly Der Spiegel shared Schmidt's concern with political instability, ${ }^{26}$ dismissing 'Polish romantic

22 Guzik (2009).

23 Sonik (2009).

24 This production could have satisfied most Polish viewers (as can be seen from their responses on the YouTube web site), but it found generally far less viewers than the original video to which it responded. The fact that Włóka is real makes her look less real; the artistic imagination that gave rise to the original video led to the creation of a story that appears far more authentic than a somewhat pedestrian depiction of a real person! For more information about the video and a web link, see: <http://wyborcza.pl/1,76842,6688700,UE_ poprawila_spot_i_dodala_Bono_zobacz_film_.html> (accessed 5 January 2010).

25 FAZ (1981) and Reißmüller (1981).

26 Augstein (1981). 
dreams of greatness' and blaming the Solidarity movement for endangering peace in Europe. ${ }^{27}$ Similar arguments were also advanced by Willy Brandt in his new role as the leader of the Socialist International. ${ }^{28}$

Poles' perceptions of indifference to their plight extend to the immediate aftermath of the demise of communism in Central and Eastern Europe, when Western Europeans were preoccupied with Western European integration and the unification of Germany, rather than the enlargement of the European Union. Furthermore, Polish citizens were not able to take full advantage of European citizenship even years after their accession to the European Union, owing to the transitional measures described earlier, which restrict freedom of movement in a number of Western European countries.

To understand the intensity of Polish responses to the twentieth anniversary video, it is important to bear in mind that this was not just an isolated case of misunderstanding. Two more recent examples will show that there is a broader pattern of biased representation of history that offends Polish sensitivities, with similar misconceptions about European history identified in school textbooks in France and Germany, and an EU museum concept.

The first is the publication of a Franco-German history textbook for secondary schools, Histoire/Geschichte: L'Europe et le monde depuis 1945/Europa und die Welt seit 1945, which might contribute to the reconciliation between France and Germany, but at the expense of serious distortions of other European countries, including Poland. As a Polish historian and MEP (PiS), Wojciech Roszkowski, argued in a detailed study, amongst the major omissions in the book is its failure to mention the Soviet invasion of Poland on 17 September 1939 and, once again, the contribution of Solidarność. One does not need to accept all of Roszkowski's harsh criticisms ${ }^{29}$ to see the shortcomings of an account of European history that - as a more sympathetic book reviewer put it - has a 'scent of the core European stable' (in a clear allusion to the excessive focus on the French and German contribution to European integration). ${ }^{30}$

27 In a similar way, Theo Sommer, wrote in the weekly Die Zeit, 'it is not necessary to approve of the perfect military putsch of General Jaruzelski... Yet, we must wish it to be successful. The next act in this Polish drama would have been otherwise a massive military intervention' (Sommer 1981).

28 FAZ, 22 December 1981.

29 He proclaimed the publication 'a failure', concluding: 'The intention of creating common French-German memory in the young generation has become all the world to the authors. Since...European integration takes so much space then why is there no information about problems of Ireland, Sweden, Finland, Denmark, Italy, Portugal, Greece or Cyprus, not to mention Eastern and Central Europe[an] countries? The knowledge from the textbook will shape the student's incorrect belief that overcoming German and French nationalisms has enabled Europe to solve its main problems and that these two countries are supposed to play a special role in Europe and their mission is to manage the affairs of the European Union and European historical memory' (see $<$ http://www.euroclio.eu/download/2009/Wojciech\%20Roszkowski\%20-\%20Criticism \%20of\%20New\%20 History\%20Textbook.pdf $>$, viewed 5 May 2010).

30 Hanimann (2006). 
Alongside schools, museums play a crucial role in shaping public perceptions of history and its meaning. This underlines the importance of the second, similar controversy triggered by the proposed design of the 'House of European Memory', which was initiated by the then President of the European Parliament, Dr Hans-Gert Pöttering. The proposal for the museum was drafted by a select group of experts drawn from across political and national divides, and was carefully framed in language that aimed to present a neutral view. Yet, the agreed 'conceptual basis for a House of European History' still prompted official protests from numerous MEPs, mainly from the new member states, who were concerned about 'a number of serious omissions and misinterpretations' ${ }^{31}$

\section{November 1989, Commemorated in Berlin on 9 November 2009}

It appears that the West learned a lesson from the embarrassment and discord caused by the ill-conceived EU video production commemorating the 1989 revolutions. By the time of the actual celebrations of the fall of the wall, there was a clear sense that this was a truly European, or indeed a world, event that should not be considered in isolation. The city of Berlin, with the participation of the European Commission's Directorate-General for Communication and the EC Representation in Berlin, organised the 'Festival of Freedom'. In an elaborate installation consisting of 1000 giant styrofoam dominoes, a section of the Berlin Wall was 'reconstructed' in order to invoke the sequence of revolutionary events in 1989. Fittingly, the person asked to topple the first of these dominoes was none other than Lech Wałęsa. The domino pieces were decorated by school children from all around the world, depicting past and present divisions caused by political conflicts, with the first one stating simply 'es began in Polen' (it started in Poland).

The event was attended by world leaders representing the former Allies, each of whom addressed a large gathering of the people of Berlin: the French President, Nicholas Sarkozy, the Russian President, Dmitry Medvedev, the British Prime Minister, Gordon Brown, and the US Secretary of State, Hillary Clinton. In the spirit of Franco-German friendship, the first guest invited to present a speech was Sarkozy. He started by complimenting the people gathered:

\footnotetext{
31 The letter addressed to the President of the European Parliament, dated 4 December 2008, listed 22 objections to the 'Conceptual Basis for a House of European History' and was signed by 13 MEPs starting with Adam Bielan and Wojciech Roszkowski (both from the Polish conservative Law and Justice Party, which recently became a crucial partner for the British Conservatives in creating a new anti-federalist group, the 'European Conservatives and Reformists') and finishing with György Schöpflin (a distinguished political scientist from the Hungarian Fidesz Party, which is a member of the 'Group of the European People's Party'). See < http://www.roszkowski.pl/www/media/files/aktualnosci/2008/34/List_ws_Domu_Historii.pdf>
} 
On 9 November 1989, you, the people of Berlin, changed the world by realizing your dream, the dream of freedom. On 9 November 1989, the whole world looked at Berlin, as you, the people of Berlin, brought down the wall of shame...This was possible because freedom-loving men and women dared to dream about [the] European ideal. ${ }^{32}$

Sarkozy continued by stressing the importance of Franco-German 'friendship, brotherhood and solidarity' for peace in Europe. He concluded by highlighting the message that 'a reconciled Europe proudly embodies and projects to the wider world: "Wir sind Brüder, wir sind Berliner"". ${ }^{33}$

Sarkozy's speech was marred by three gaffes. First, he mispronounced the German concluding sentence, causing his attempt to emulate Kennedy's famous 'Ich bin ein Berliner' to fall flat. Second, Sarkozy's relentless desire to be at the heart, if not the cause, of major events led him to claim that he was in Berlin on 9 November 1989. His official Facebook page showed a photograph of the then young politician chipping off parts of the wall, as so many people of Berlin, as well as tourists from all around the world, did at the time. The revelation that Sarkozy actually arrived in Berlin only a few weeks later caused major embarrassment and was widely covered in the media worldwide. It was the third, and least noticed, gaffe, however, that is relevant to this study. As had many an EU official account in the past, ${ }^{34}$ Sarkozy disregarded the sequencing of events by saying that 'you [the people of Berlin] tore down this wall, which everyone deemed indestructible, and from this day onwards other nationsBulgaria, Czechoslovakia, Hungary and Poland-freed themselves from tyranny' (my italics). ${ }^{35}$

Sarkozy's gaffes unwittingly reveal that 'EU Europe' still has a long way to go in reaching a self-understanding that would be acceptable to all its members, old and new. Disregarding Sarkozy's emphasis on Franco-German perspectives, there are other reasons why any celebrations of 9 November in Germany have to be approached with the utmost caution. As current German Chancellor, Angela Merkel, and most leading German editorials recognised, the day is laden with multiple meanings reflecting the contradictory nature of German history. The somewhat accidental announcement of the end of the wall by the Politburo member Günther Schabowski took place on a day that is relevant to two dark aspects of the German political tradition that also shaped European politics in

\footnotetext{
32 Sarkozy (2009).

33 Ibid.

34 In line with the commemorative video discussed above, a brochure produced by the EC DirectorateGeneral for Communication, Europe in 12 Lessons, states: 'The political shape of Europe was dramatically changed when the Berlin Wall fell in 1989. This led to the unification of Germany in October 1990 and the coming of democracy to the countries of central and eastern Europe as they broke away from Soviet control' (Fontaine 2006:11; my italics).

35 Sarkozy (2009).
} 
the twentieth century: communism and Nazism. On 9 November 1918, Karl Liebknecht proclaimed the short-lived first German Socialist Republic; twenty years later, on 9 November 1938, the infamous Kristallnacht marked a turning point in Nazi persecution of the Jews. These are the reasons why the day is unlikely to ever be proclaimed in Germany as a national holiday, the repeated calls for its recognition notwithstanding. ${ }^{36}$

\section{Concluding Remarks}

It is clear that any attempt to reach a common understanding about the 'true meaning' of key moments in history - such as the demise of communism in Poland, East Germany, or Europe at large - is fraught with difficulties. Such consensus is difficult to achieve at a national level; to aspire to its achievement at the EU level is bound to backfire. The juxtaposition of uplifting narratives produced by the European Commission with the many messy histories of participating nations points towards the limits of the usage of history for political aims, however worthy those aims might be. Yet, there are also some positive lessons that can be drawn from the dissonance caused by the European Union's attempts to appropriate the legacy of 1989.

France, Germany and the supranational institutions of the European Union, such as the European Commission, will need to learn to accept that they are no longer exclusively at the heart of the European project. In line with this, some of the key assumptions that drove the European project from its early stages are being challenged as a result of the massive political transformation brought about by the events of 1989. The postwar project of European unity in the West was informed by the rejection of nationalism as a destructive force, whereas in the communist part of Europe, nationalism was experienced as a liberating force. ${ }^{37}$ The project in the West was shaped by the experience of Nazism; after 1989, the notion of 'never again Nazism' had to be complemented with 'never again Stalinism'.

Reflecting on the changed nature of Europe twenty years after the collapse of communism, a perceptive British sociologist proclaimed boldly that 'we are all post-communist now' ${ }^{38}$ This is to be understood not as a description of political reality in contemporary Europe, but rather as a challenge that European nations and their elites in both East and West must take seriously, if the European

\footnotetext{
36 Kohler (2009).

37 Auer (2004).

38 Admittedly, this notion will sound strange to Polish readers accustomed to using the term 'postcommunist' to describe those who were once communist. As Outhwaite (2009:52) explains, the dictum is used 'in the sense that Europe as a whole, as well as the European Union, has been radically transformed by what happened in and around 1989 in the communist half of the continent'.
} 
project is to succeed. In a similar vein, when Jerzy Buzek, upon his election as President of the European Parliament, proclaimed in his acceptance speech that 'there is now no "you" [in the West] and "us" [in the East]: we live in a shared Europe', ${ }^{39}$ it was a statement of intent, rather than a statement of fact. Debates about key historical events and their meaning serve as a reminder that there are still significant divisions between the two parts of Europe that used to be divided by the Iron Curtain, just as there are divisions between the nations of Europe regardless of their geographic location. Yet, to accept that a Europe of 27 nation-states must live with discord is true to the legacy of the European Union's founding fathers, such as Jean Monnet and Konrad Adenauer, as much as it is to the legacy of the architects of the velvet revolutions of 1989, such as Adam Michnik and Václav Havel. With their mixture of idealism and pragmatism, these Europeans understood that the true meaning of politics consists of accepting dissonance, while not giving up aspirations for more harmony.

Note: The author would like to gratefully acknowledge financial support from the Australian Research Council for the Discovery Grant entitled 'The Spectre of Velvet Revolution', and from the Institute of European Democrats (IED) in Brussels. The author would also like to thank Robert Horvath, Gosia Klatt, Jan Pakulski, Tony Philips, Robert Podbereski, Dougles Webber, and especially Nicole Scicluna, for their feedback and help.

\section{Bibliography}

Ash, T. G. 1993. In Europe's Name: Germany and the divided continent, Random House, New York.

Auer, S. 2004. Liberal Nationalism in Central Europe, Routledge, London.

Augstein, R. 1981. 'Die Polnische Tragödie', Der Spiegel, vol. 35, no. 52 (21 December), p. 88.

Bruter, M. 2005. Citizens of Europe? The emergence of a mass European identity, Palgrave Macmillan, Basingstoke, UK.

Chaffin, J. and Cienski, J. 2009. 'MEPs elect Poland's Buzek to presidency', Financial Times, 14 July.

Clark, C. 1997. 'Forging identity: Beethoven's "Ode" as European anthem', Critical Inquiry, no. 23, pp. 789-807.

Darnton, R. 2002. 'Euro state of mind', New York Review of Books, pp. 30-2.

39 Chaffin and Cienski (2009). 
Dubiel, H. 2003. 'The remembrance of the Holocaust as a catalyst for a transnational ethic?', New German Critique, no. 90, pp. 59-70.

Fontaine, P. 2000. The Schuman Declaration, Office for Official Publications of the European Communities, Luxembourg.

Fontaine, P. 2006. Europe in 12 Lessons, European Communities, Brussels.

Frankfurter Allgemeine Zeitung (FAZ) 1981. 'Schatten aufWerbellin', Frankfurter Allgemeine Zeitung, 14 December.

Genscher, H.-D. 1995. Erinnerungen, Siedler Verlag, Berlin.

Guzik, J. 2009. 'Poprawią spot o rocznicy upadku komunizmu', Rzeczpospolita, 18 May.

Hainsworth, P. 2006. 'France says no: the 29 May 2005 referendum on the European Constitution', Parliamentary Affairs, vol. 59, no. 1, pp. 98-117.

Hanimann, J. 2006. 'Kerneuropäischer Stallgeruch', Frankfurter Allgemeine Zeitung, 8 May, p. 43.

Havel, V. 1992. Summer Meditations, Alfred A. Knopf, New York.

Kohl, H. 2005. Erinnerungen 1982-1990, Droemer, München.

Kohler, B. 2009. 'Der Tag der Deutschen', Frankfurter Allgemeine Zeitung, 10 November, p. 1.

Korte, K.-R. 1998. Deutschlandpolitik in Helmut Kohls Kanzlerschaft: Regierungsstil und Entscheidungen 1982-1989, Deutsche Verlags-Anstalt, Stuttgart.

Krzeminski, A. 2001. 'Der Kniefall', in H. Schulze and E. Francois (eds), Deutsche Erinnerungsorte 1, Beck, München, pp. 431-46.

Larat, F. 2005. 'Present-ing the past: political narratives on European history and the justification of EU integration', German Law Review, vol. 6, no. 2, pp. 273-90.

Leonard, M. 2005. Why Europe Will Run the 21st Century, Fourth Estate, London.

Mayer, F. C. and Palmowski, J. 2004. 'European identities and the EU- the ties that bind the peoples of Europe', Journal of Common Market Studies, vol. 42, no. 3, pp. 573-98.

Monnet, J. 1978. Memoirs, Collins, London.

Outhwaite, W. 2009. 'Europe beyond East and West', in C. Rumford (ed.), The SAGE Handbook of European Studies, Sage, London, pp. 52-68. 
Pfaff, W. 2007. 'Happy birthday!', New York Review of Books, vol. 54, no. 7, p. 20.

PPN 1978. 'Niemcy a Polska', Kultura, no. 7, pp. 123-9.

Reißmüller, J. G. 1981. 'Deutsche Verhältnisse', Frankfurter Allgemeine Zeitung, 16 December, p. 1.

Sarkozy, N. 2009. Staatspräsident Sarkozy in Berlin zum 20. Jahrestag des Falls der Berliner Mauer, <http://www.botschaftfrankreich.de/spip. php?article4424>

Schmidt, H. 1989. Men and Powers: A political retrospective, Random House, New York.

Schröder, G. 2000. ‘Ohne polnisches Freiheitsstreben wäre die Geschichte der deutschen Einheit weniger glücklich verlaufen', Frankfurter Allgemeine Zeitung, 7 December, p. 10.

Schwarz, H.-P. (ed.) 2009. Die Fraktion als Machtfaktor: CDU/CSU im deutschen Bundestag 1949 bis heute, Bertelsmann, Munich.

Sommer, T. 1981. 'Ruckfall in den Kalten Krieg?', Die Zeit, 18 December, p. 1.

Sonik, B. 2009. Sonik żąda wycofania spotu Komisji Europejskiej, <http://www. boguslawsonik.pl/index.php?nr2=587>

Stein, E. 1981. 'Lawyers, judges and the making of a transnational constitution', American Journal of International Law, vol. 75, no. 1, pp. 1-27.

Trouille, J. M. 2002. 'France, Germany and the eastwards expansion of the EU: towards a common Ostpolitik', in H. Ingham and M. Ingham (eds), EU Expansion to the East: Prospects and problems, Edward Elgar, Cheltenham, UK, pp. 50-64.

Uhlig, D. 2009. 'Bruksela o wolności bez "Solidarności"”, Gazeta Wyborcza, 16 May.

Uhlig, D. and Pszczółkowska, D. 2009. 'Bruksela (może) doklei "Solidarność"”, Gazeta Wyborcza, 19 May.

Weiler, J. 1994. 'A quiet revolution: the European Court of Justice and its interlocutors', Comparative Political Studies, vol. 26, no. 4, pp. 510-34.

Zaborowski, M. 2005. Germany, Poland and Europe: Conflict, cooperation and Europeanization, Manchester University Press, Manchester.

Ziemer, K. 2008. 'The Polish cause and the German cause in the 20th century', The Polish Quarterly of International Affairs, no. 1, pp. 119-37. 